\title{
Electrochemical Corrosion Study of Metallic Materials in Phosphoric Acid as Bipolar Plates for HT-PEFCs
}

\author{
V. Weissbecker, ${ }^{\mathrm{a}, \mathrm{z}}$ K. Wippermann, ${ }^{\mathrm{a}}$ and W. Lehnert ${ }^{\mathrm{a}, \mathrm{b}, *}$ \\ ${ }^{a}$ Forschungszentrum Jülich GmbH, Institute of Energy and Climate Research, IEK-3: Electrochemical Process \\ Engineering, 52425 Jülich, Germany \\ ${ }^{b}$ Modeling in Electrochemical Process Engineering, RWTH Aachen University, 52056 Aachen, Germany
}

\begin{abstract}
This work investigates various commercially available austenitic stainless steels and Ni-based alloys as possible metallic bipola plates for high-temperature polymer electrolyte fuel cells (HT-PEFCs). The dynamic formation and depletion of passivation layers that depends strongly on applied potential was analyzed in $85 \mathrm{wt} \%$ phosphoric acid at RT and $130^{\circ} \mathrm{C}$ by means of cyclic voltammetry and steady-state polarization. All materials showed a beneficial passivation in the potential window $0.3-1.2 \mathrm{~V}$, which is mainly based on a stable inner $\mathrm{Cr}_{2} \mathrm{O}_{3}$ layer, and a reduction of the passive layers at cathodic polarization. Alloy 2.4869 (Cronix 80) with $80 \mathrm{wt} \%$ $\mathrm{Ni}$ and $20 \mathrm{wt} \% \mathrm{Cr}$ reveals the lowest corrosion rates of $16.1 \mu \mathrm{A} \mathrm{cm}^{-2}$ at $130^{\circ} \mathrm{C}$ in the passive region at $0.6 \mathrm{~V}$ and a free corrosion potential $\mathrm{E}_{\mathrm{cor}}$ of $235 \mathrm{mV}$. The improvement of passivity was achieved by the dominant superficial $\mathrm{Ni}_{3}\left(\mathrm{PO}_{4}\right)_{2}$ layer. Alloying additions Mo and Ti revealed a characteristic increase of passive current densities due to instability of these passivation components at $130^{\circ} \mathrm{C}$. Passivation based on Fe oxides and phosphates in stainless steels shows to be beneficial at RT, but less efficient at $130^{\circ} \mathrm{C}$. (C) 2014 The Electrochemical Society. [DOI: 10.1149/2.0691414jes] All rights reserved.
\end{abstract}

Manuscript submitted September 5, 2014; revised manuscript received October 2, 2014. Published October 14, 2014. This was Paper 1371 presented at the San Francisco, California, Meeting of the Society, October 27-November 1, 2013.

High-temperature polymer electrolyte fuel cells (HT-PEFCs) operate in the range of $120-180^{\circ} \mathrm{C}$ and currently employ phosphoric acid doped polybenzimidazole membranes. This in turn represents a quite aggressive environment for the components of a fuel cell. Presently, bipolar plates are made of graphitic composite materials. Significant drawbacks are the apparent corrosion rates, a high effort of manufacturing and the uptake of phosphoric acid. Previous studies have demonstrated a wide range of corrosion current densities for different types of graphite up to the level of $1 \mathrm{~mA} \mathrm{~cm}{ }^{-2}$ in $\sim 100 \mathrm{wt} \% \mathrm{H}_{3} \mathrm{PO}_{4}$ at $185-200^{\circ} \mathrm{C}$ depending strongly on polarization, amount of binders or resins and heat-treatment. ${ }^{1,2}$ The porous structure of graphitic composites causes a considerable uptake of phosphoric acid between 10 and $25 \mathrm{wt} \%$ of the entire phosphoric acid content of the MEA after $1600 \mathrm{~h}^{3}$ Consequently, this induces a mitigation of the protonic conductivity and a limitation of the fuel cell performance. Therefore, metallic materials come into play as promising candidates for bipolar plates. They provide some crucial advantages, like increased ductility, high electronic conductivity, a negligible acid uptake and the capability of low-cost mass production by stamping and hydroforming. For instance, the stack costs can be reduced by $25 \%$ compared to graphitic bipolar plates. ${ }^{4-6}$ The integration of metallic bipolar plates is also the key issue to enhance the volumetric and gravimetric power density due to a more compact design. The challenge of this approach is the lack of fundamental understanding of the electrochemical corrosion of the bipolar plate in contact with phosphoric acid at elevated temperatures. In addition to the common corrosion in acidic environment, the cathode compartment of a fuel cell is exposed to a higher polarization. Thus, it is a crucial task to investigate the corrosion process, which is affected by potential in order to select proper materials.

Basically, alloys with a high amount of $\mathrm{Cr}(\sim 20 \%)$ and $\mathrm{Ni}$ $(>50 \%)$ are suitable for the exposure in phosphoric acid at elevated temperatures due to passivation of the metallic surface. Moreover, small amounts of $\mathrm{Mo}, \mathrm{Nb}, \mathrm{Ta}$ or $\mathrm{W}$ enhance the corrosion resistance, which is attributed to stable metal oxides..$^{7-9}$ Mainly $\mathrm{Cr}$ (III)-oxide as the core component is responsible for the passive film formation (inner passive layer). Additionally, dissolved metal ions form insoluble hydroxides and phosphates (outer passive layer) in phosphoric acid. At temperatures below $100^{\circ} \mathrm{C}$ the outer passive layer consists primarily of $\mathrm{Cr}$ and $\mathrm{Fe}$ phosphates and hydroxides, ${ }^{10,11}$ whereas at higher temperatures Ni-phosphates represent the main fraction. ${ }^{12,13}$ Investigations on the composition of passive films after exposure to

${ }^{*}$ Electrochemical Society Active Member.

${ }^{\mathrm{z}}$ E-mail: v.weissbecker@fz-juelich.de phosphoric acid at RT confirm an enrichment of $\mathrm{Fe}$ and $\mathrm{Cr}$ in the inner part and Mo in the outer region of passive layers concerning steels with a low Ni content. In contrary, in terms of Ni-based alloys mostly $\mathrm{Fe}, \mathrm{Cr}$ and $\mathrm{Mo}$ have been found in the outer and $\mathrm{Ni}$ in the inner passive layer. ${ }^{14,15}$ Further studies reveal that Mo can only build up passivation by interaction with $\mathrm{Cr}$ and $\mathrm{Fe}$ in the form of mixed complex phosphates at the interface electrolyte/passive layer. ${ }^{16-18}$ The beneficial effect of $\mathrm{W}$ derives from embedding $\mathrm{WO}_{3}$ in the superficial layer. ${ }^{19,20}$ Unfortunately, passivation mechanism and passive layer stability in phosphoric acid for temperatures above $100^{\circ} \mathrm{C}$ are missing throughout.

Literature references referring corrosion of metallic bipolar plates of PEFCs, which operate at a temperature of about $85^{\circ} \mathrm{C}$ with Nafion as proton conductive membrane, are widely shared. ${ }^{4,21-24}$ But in terms of HT-PEFC, activities in the field of metallic bipolar plates and their degradation are relatively low. Due to enhanced temperatures and the interaction between different metal species and phosphates, the formed passive layer has different chemical properties than that built up at usual PEFC conditions. Wang and Turner reported about the formation of passivation layers on austenitic stainless steels in $98 \mathrm{wt} \%$ $\mathrm{H}_{3} \mathrm{PO}_{4}$ at $170^{\circ} \mathrm{C}$. After polarization the Fe-oxide layer dissolved selectively, while the Cr-oxide layer was more stable. High corrosion rates of $1.43 \mathrm{~mA} \mathrm{~cm}^{-2}$ for anodic and $1.7 \mathrm{~mA} \mathrm{~cm}^{-2}$ for cathodic conditions were detected for alloy $904 \mathrm{~L}$, as the most appropriate candidate. By comparing with carbon composite, the anodic current densities of alloy 904L are in the same range or even lower. ${ }^{25}$ Further publications exhibit the lowest corrosion rates for alloy 625, Ta and $\mathrm{SiC}$ coatings in phosphoric acid at $150^{\circ} \mathrm{C}$. Highly alloyed steels like 904L with a Fe content of around 50\% keep their passivity only up to $120^{\circ} \mathrm{C}$. Ti shows the worst resistance in phosphoric acid compared to stainless steels, Ni-based alloys, $\mathrm{SiC}$ coatings and the metals $\mathrm{Nb}$ and $\mathrm{Ta}^{26-28}$

The present work evaluates the significance and constraints of passive layers on metallic surfaces in terms of corrosion resistivity in $85 \mathrm{wt} \% \mathrm{H}_{3} \mathrm{PO}_{4}$ at RT and $130^{\circ} \mathrm{C}$. Various commercial austenitic stainless steels as well as Ni-based alloys with additions of $\mathrm{Mn}, \mathrm{Mo}, \mathrm{Al}$, $\mathrm{Ti}, \mathrm{Cu}, \mathrm{W}$ and $\mathrm{Nb}$ were examined. All tested materials and accordingly their compositions are listed in Table I. Measurements without polarization were carried out to determine the protective passive layer formation on the metal surface and the correlating development of the free corrosion potential $\mathrm{E}_{\mathrm{cor}}$, which is strongly affected by temperature. Further cyclic voltammetry and quasi steady-state polarization were performed in order to get information about anodic corrosion currents, partial current densities $j_{\text {cor }}$ and the impact of the containing elements under polarization. 


\begin{tabular}{|c|c|c|}
\hline Material & & Chemical composition / wt $\%$ \\
\hline 1.4301 & AISI 304 & $\mathrm{FeCr} 18 \mathrm{Ni} 10$ \\
\hline 1.4372 & AISI 201 & FeCr17Ni5Mn7 \\
\hline 1.4404 & AISI 316L & $\mathrm{FeCr} 17 \mathrm{Ni} 12 \mathrm{Mo} 2$ \\
\hline 1.4571 & AISI 316Ti & FeCr17Ni12Mo2Ti1 \\
\hline 1.4539 & Alloy $904 \mathrm{~L}$ & $\mathrm{FeCr} 20 \mathrm{Ni} 25 \mathrm{Mo} 5 \mathrm{Cu} 2$ \\
\hline 1.4876 & Nicrofer $3220 \mathrm{H}$ & FeCr20Ni32Al1Ti1 \\
\hline 2.4819 & Nicrofer 5716 hMoW & FeCr15Ni57Mo16W4 \\
\hline 2.4733 & Haynes 230 Alloy & FeCr22Ni57W14Mo2 \\
\hline 2.4856 & Nicrofer 6020 hMo - Alloy 625 & FeCr22Ni58Mo9Nb4 \\
\hline 2.4869 & Cronix 80 & FeCr20Ni80 \\
\hline Graphite & Eisenhuth BBP4 & Graphite with phenolic resin \\
\hline
\end{tabular}

\section{Experimental}

Electrochemical corrosion cell.- The electrochemical corrosion tests of the metallic materials were carried out in a specially designed electrochemical cell that allows operating temperatures above $100^{\circ} \mathrm{C}$, shown in Figure 1 and Figure 2. The working electrode (WE) is pressed from outside with a circular stamp against the left exterior PTFE wall. Inside the cell, the wall is cone-shaped and has a centric opening with a diameter of $18 \mathrm{~mm}$. Thus, the WE has an effective area of $2.54 \mathrm{~cm}^{2}$ that is in contact with the electrolyte. This set-up defines a precise geometry of the WE and makes sure that there is no deviation in measurement attributed to bare edges or the holder of the sample. As counter electrode (CE) a platinum mesh with an

a)
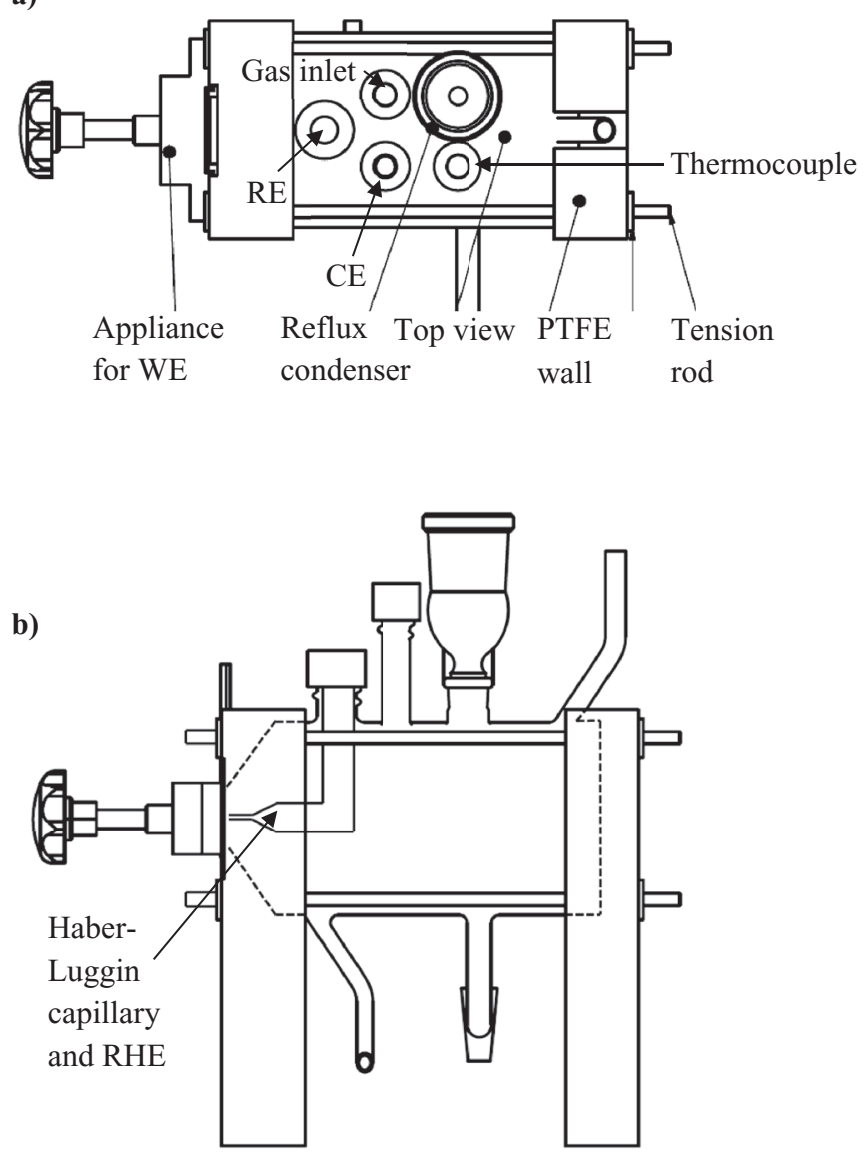

Figure 1. Drawing of the corrosion cell for measuring corrosion currents as a function of polarization and temperature: a) Top view and b) side view.

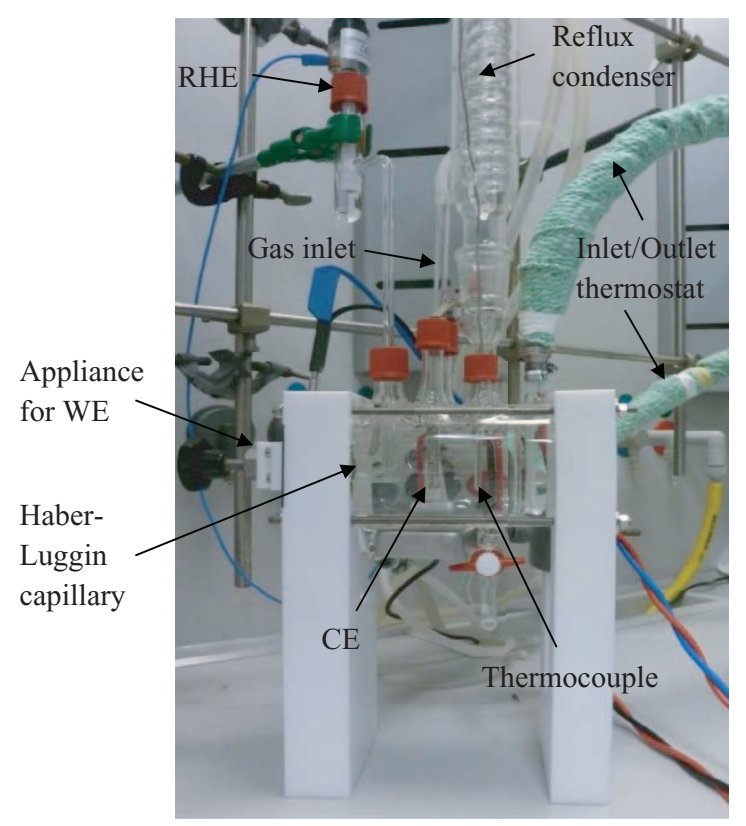

Figure 2. Picture of the three electrode corrosion cell for measuring corrosion rates in phosphoric acid as a function of polarization and temperature.

effective area of approx. $30 \mathrm{~cm}^{2}$ and as reference electrode (RE) a reversible hydrogen electrode RHE (HydroFlex, Gaskatel) were used. RHE was arranged outside of the cell in order to avoid a potential shift derived from measurements at elevated temperatures. Inside of the cell a Haber-Luggin capillary with a frit at the tip was used to ensure accurate results and to prevent contamination of the RE with metal ions, which are released in large quantities from the WE directly in front of the Haber-Luggin capillary during the corrosion process. It is very important to inhibit the diffusion of produced metal ions into the electrolyte of the RE or even to the RE itself. Primarily, the RE can work unreliable due to adsorbed metal ions on the surface and secondly, dissolved ions have an impact on the electrolyte potential and accordingly on the potential of the reference electrode. A reflux condenser assures nearly constant conditions of the electrolyte with view on water content at high temperatures.

All measurements were performed in $85 \mathrm{wt} \% \mathrm{H}_{3} \mathrm{PO}_{4}$ as it is used in doping treatments of the PBI membrane for HT-PEFC application. For the separated RE $1 \mathrm{M} \mathrm{H}_{3} \mathrm{PO}_{4}$ was employed. Phosphoric acid was purchased from VWR Chemicals (AnalaR NORMAPUR) and used without further purification.

Methodology and material characterization.- Before starting the measurements, all materials were cleaned with isopropanol, etched with $85 \mathrm{wt} \% \mathrm{H}_{3} \mathrm{PO}_{4}$ and polished with alumina paste (from Buehler) with a particle size of 5 and $0.05 \mu \mathrm{m}$, respectively. Directly after pretreatment, the metallic sample was inserted as WE and the cell was flooded with $175 \mathrm{ml} 85 \mathrm{wt} \% \mathrm{H}_{3} \mathrm{PO}_{4}$. Afterwards the cell was purged for 20 minutes with nitrogen and the sample was cleaned via voltammetry in the potential window between $-0.5 \mathrm{~V}$ and $1.4 \mathrm{~V}$ for ten cycles with a scan rate of $100 \mathrm{mV} \mathrm{s}^{-1}$. The electrochemical cleaning ends with potentiostatic holding at $-0.5 \mathrm{~V}$ for $10 \mathrm{~s}$ to ensure that the passivation layer is reduced. To guarantee a homogeneous agitation, the bulk electrolyte was stirred during all experiments with a magnetic stirrer.

The determination of the free corrosion potential $\mathrm{E}_{\mathrm{cor}}$ began immediately after the pretreatment of the sample in order to monitor the rapid passivation of the metallic surface. After 20 hours at RT, the temperature was increased continuously with a rate of $1^{\circ} \mathrm{C} \mathrm{min}-1$ within two hours up to $130^{\circ} \mathrm{C}$ and kept at this level for another two hours. Despite of the use of a reflux condenser, a further rise of temperature was not performed in this study in order to avoid high evaporation 
ratios of water in the employed $\mathrm{H}_{3} \mathrm{PO}_{4}$ that would vary the properties of the electrolyte as a consequence. All following polarization analysis were carried out after purging the cell additionally with nitrogen for 15 minutes to exclude the oxygen reduction reaction as a side reaction of hydrogen formation on the metal surface. The dynamic passive layer formation and the influence of alloying elements was examined by the means of cyclic voltammetry in the potential window $-0.5 \mathrm{~V}-1.4 \mathrm{~V}$ and $0 \mathrm{~V}-1.4 \mathrm{~V}$ at $\mathrm{RT}$ and $130^{\circ} \mathrm{C}$, respectively. The evaluation of the respective partial current densities $\mathrm{j}_{\text {cor }}$ and corrosion current densities in the active, passive and transpassive region were carried out using steady-state polarization with following thresholds: absolute current tolerance $10 \mathrm{nA} \mathrm{s}^{-1}$, minimum delay $1 \mathrm{~s}$ and maximum delay $60 \mathrm{~s}$. The study was performed in the potential range from $-0.5 \mathrm{~V}$ to 2.0 $\mathrm{V}$ and $0 \mathrm{~V}$ to $1.0 \mathrm{~V}$ at RT and accordingly from $-0.5 \mathrm{~V}$ to $1.4 \mathrm{~V}$ and $0 \mathrm{~V}$ to $1.0 \mathrm{~V}$ at $130^{\circ} \mathrm{V}$. A temperature tolerance of $5^{\circ} \mathrm{C}$ was estimated throughout due to the glass coating of the thermocouple in the cell and the gradual heating phases of the thermostat Haake DC30. The potential was always measured against RHE at RT in $1 \mathrm{M} \mathrm{H}_{3} \mathrm{PO}_{4}$. The influence of the diffusion potential $E_{\text {diff }}$ derived from different phosphoric acid concentrations in bulk electrolyte $(\sim 15 \mathrm{M})$ and RE $(1 \mathrm{M})$, was considered to be $40 \mathrm{mV}$ at RT and $42 \mathrm{mV}$ at $80^{\circ} \mathrm{C}$. For temperatures above $100^{\circ} \mathrm{C}, E_{\text {diff }}$ is expected in the same range due to similar proton activity coefficients and dissociations constants. ${ }^{29}$ Tafel plots as well as $\mathrm{E}_{\text {cor }}$ and $\mathrm{j}_{\text {cor }}$ were calculated by using the software Thales. All analyses were accomplished with the potentiostat IM-6 provided by Zahner.

\section{Results and Discussion}

Free corrosion potential $E_{c o r}$ - passivation as a natural protection layer- - Austenitic stainless steels as well as alloys with high $\mathrm{Ni}$ content belong to the most suitable metallic materials for the use in phosphoric acid. The classification is made according to the elemental composition. Stainless steels exhibit an enormous amount of iron $(65-70 \%)$, whereas Ni-based alloys have an iron content lower than $50 \%$, but a high quantity of nickel (up to $80 \%$ ). The Cr contents, which play a significant role for formation of stable oxide layers, are within the range of $15-22 \%$, respectively. Moreover, there are additions of $\mathrm{Mn}, \mathrm{Mo}$ and $\mathrm{Ti}$ in the case of stainless steels as well as $\mathrm{Cu}$, $\mathrm{Mo}, \mathrm{Al}, \mathrm{Ti}, \mathrm{W}$ and $\mathrm{Nb}$ in the category of Ni-based alloys. Apart from metallic materials, the graphite composite material BBP4 (Eisenhuth) with phenolic resin for operating temperatures up to $180^{\circ} \mathrm{C}$ was also tested for comparison. All examined materials and their elemental composition are specified in Table I.

First of all, measurements of the free corrosion potential $\mathrm{E}_{\text {cor }}$ were executed in $85 \mathrm{wt} \%$ phosphoric acid in order to observe the thermodynamics of metals passivation. Basically, electrochemical corrosion phenomena at the interface electrode/electrolyte (in our case metal/phosphoric acid) in acidic solutions underlie at least two partial simultaneous reactions, namely the release of metal ions from the electrode (anodic reaction, eq. 1) and the formation of hydrogen at the metallic surface (cathodic reaction, eq. 2).

$$
\begin{gathered}
\mathrm{Me} \rightleftharpoons \mathrm{M} e^{z+}+z e^{-} \\
2 \mathrm{H}_{3} \mathrm{O}^{+}+2 e^{-} \rightleftharpoons \mathrm{H}_{2}+2 \mathrm{H}_{2} \mathrm{O} \\
\mathrm{O}_{2}+4 \mathrm{H}_{3} \mathrm{O}^{+}+4 e^{-} \rightleftharpoons 6 \mathrm{H}_{2} \mathrm{O}
\end{gathered}
$$

The oxygen corrosion as possible additional cathodic reaction (eq. 3) can be neglected due to the purging of the electrochemical cell with $\mathrm{N}_{2}$ and a very low $\mathrm{O}_{2}$ solubility in concentrated phosphoric acid of $\sim 1.7 \cdot 10^{-4} \mathrm{M}$ compared with $1.3 \cdot 10^{-3} \mathrm{M}$ in water. ${ }^{30,31}$ The extent of the metal dissolution corresponds to the rate of hydrogen evolution, i.e. all generated electrons in the anodic reaction must be dissipated in the cathodic reaction due to electroneutrality. Using simple thermodynamic considerations (eq. 4 and eq. 5), the tendency of occurring corrosion can be predicted by taking into account the potentials of oxidation and reduction, respectively, where $\Delta G$ describes the change in the Gibbs' enthalpy

$$
\begin{gathered}
\Delta G=-z F \Delta E \\
\Delta E=E_{R e d}-E_{O x}
\end{gathered}
$$

with $z$ the number of electrons exchanged in the reactions, $F$ the Faraday constant and $\Delta E$ the difference between the cathodic $\left(E_{R e d}\right)$ and the anodic potential $\left(E_{O x}\right)$. Theoretically, the respective reaction potentials can be obtained from the Nernst equation (eq. 6) as a function of temperature and ion activities where $E^{0}$ is the standard potential known from the electrochemical series, $a$ the activities of the ion species and $v$ the stoichiometric factor. $R$ and $T$ have their usual meaning as the ideal gas constant and temperature.

$$
E=E^{0}+\frac{R T}{z F} \ln \frac{\prod^{a_{O x}^{v}}}{\prod^{a_{\text {Red }}^{v}}}
$$

For proceeding corrosion, however, conventional standard conditions cannot be assured by following reasons. The activity of participating ion species varies strongly over time attributed to ongoing metal dissolution or precipitation of passive layers based on metal oxides and phosphates. Further, these passive films with different behavior as the bare metal lead to a kinetic barrier against metal dissolution. Moreover, a corroding metal is both anode and cathode at the same time (local element). Hence, there cannot exist common double layer properties, which are responsible for charge transfer control and thus the typical electrode potential. Therefore, it is hardly possible to estimate the anodic and cathodic electrode potential of a corroding metal.

In practical case, the free corrosion potential $\mathrm{E}_{\mathrm{cor}}$ is introduced to monitor the corrosion behavior of metals. $\mathrm{E}_{\mathrm{cor}}$, as the resulting mixed potential, is located between the anodic and the cathodic potential of the reactions. In general terms, corrosion can only be suppressed, when $\Delta G$ of the overall reaction is positive (endergonic reaction) and this is only feasible when the anodic potential exceeds the cathodic potential, see eq. 4 and 5. In other words, this means the higher $E_{\text {cor }}$ of a metal, the higher the anodic potential. The importance of $E_{\text {cor }}$ of different stainless steels in various acidic solutions in described elsewhere. ${ }^{32}$ Thus, determining $\mathrm{E}_{\text {cor }}$ is an indication for stability of the material against electrochemical corrosion for the case when no external current is applied.

Figure 3 shows the progress of the free corrosion potential $\mathrm{E}_{\mathrm{cor}}$ of austenitic stainless steels and Ni-based alloys within 20 hours at RT. In Figure $3 \mathrm{a}$, the rise of $\mathrm{E}_{\text {cor }}$ from about $-90 \mathrm{mV}$ to $300 \mathrm{mV}$ occurs relatively fast within the first 2.5 hours, whereas the further increase of $E_{\text {cor }}$ up to $425 \mathrm{mV}$ after 20 hours is rather slowly. Remarkable is the rapid initial rise and the higher level of $\mathrm{E}_{\mathrm{cor}}(525 \mathrm{mV})$ of material 1.4571 (AISI 316Ti). The presence of $\sim 1 \%$ Ti leads to the formation of stable titanium carbide inside the metal lattice and this has probably an influence on passivation. 2\% of Mo in 1.4404 (AISI 316L) and 1.4571 does not have any positive effect on $\mathrm{E}_{\text {cor }}$ compared to the standard stainless steel 1.4301 (AISI 304). The addition of Mn seems to accelerate the passivation only in the early stage.

On the other side Ni-based alloys in Figure $3 \mathrm{~b}$ show more distinct differences in the two-step shape of the curves. Here the effect of the supported elements is not so obvious, because the basic composition including $\mathrm{Fe}, \mathrm{Cr}$ and $\mathrm{Ni}$ is varying strongly. The sample 1.4876 (Nicrofer $3220 \mathrm{H}$ ) with $1 \% \mathrm{Al}$ and $\mathrm{Ti}$, respectively, reveals a fast passivation with the highest $\mathrm{E}_{\text {cor }}$ of $510 \mathrm{mV}$ after 20 hours, which is comparable to the stainless steel 1.4571 , containing also $1 \% \mathrm{Ti}$. Another very significant alloy in our experimental series in terms of quick passivation is 2.4869 (Cronix 80 ) with a $\mathrm{Ni}$ amount of $80 \%$. This sample consists only of the elements $\mathrm{Cr}$ and $\mathrm{Ni}$ and surprisingly reveals the same shape of the curve as the other materials. Therefore, we believe that the first initial step up to $20 \mathrm{mV}$ is assigned to a rapid formation of $\mathrm{Cr}_{2} \mathrm{O}_{3}$ (inner main passivation) and the second step to the slower growth of the outer Ni-phosphate crystals. Regarding the other materials, the superficial layer can also include Fe-phosphates or $\mathrm{Mo} / \mathrm{W}$-oxides, as it was discussed above. The remaining alloys 1.4539 (alloy 904L), 2.4819 (Nicrofer 5716 hMoW), 2.4733 (Haynes 

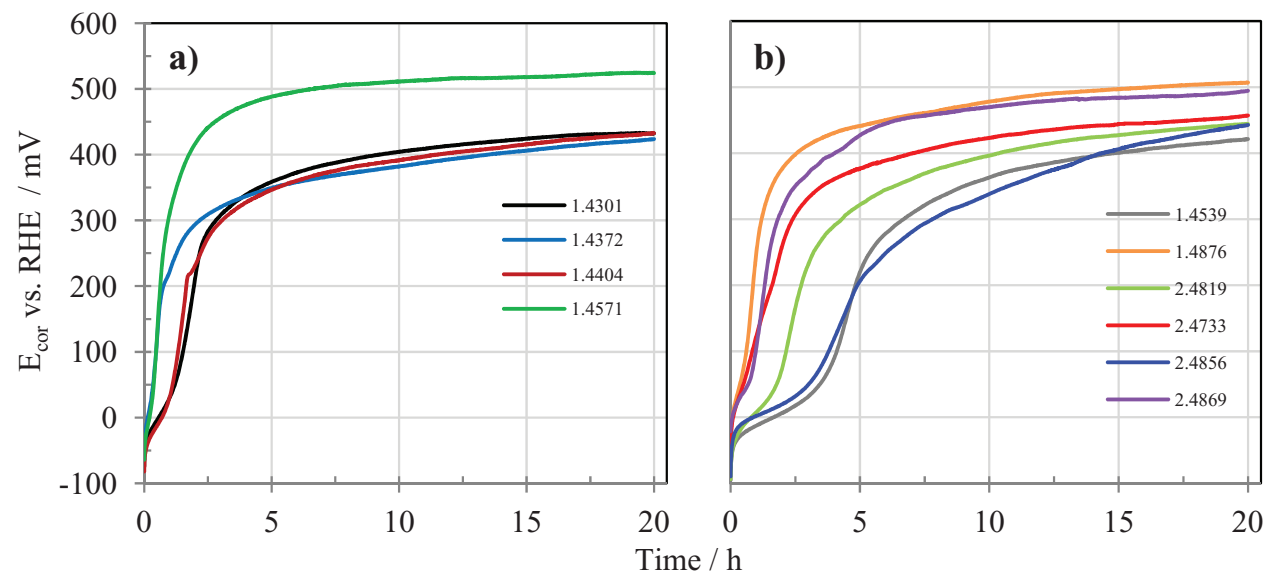

Figure 3. Progress of $\mathrm{E}_{\text {cor }}$ measured in $85 \mathrm{wt} \% \mathrm{H}_{3} \mathrm{PO}_{4}$ at $\mathrm{RT}$ for $20 \mathrm{~h}$ : a) Austenitic stainless steels and b) Ni-based alloys.

230 alloy) and 2.4856 (Nicrofer $6020 \mathrm{hMo}$ ) with a final value of $420-455 \mathrm{mV}$ after 20 hours exhibit no improvement by additions of $\mathrm{Cu}, \mathrm{Mo}, \mathrm{W}$ and $\mathrm{Nb}$. Remarkable is the fact that an enhanced amount of Mo (1.4539, 2.4819 and 2.4856) emerges a slow increase of $\mathrm{E}_{\mathrm{cor}}$, which can be probably inferred from the diminished kinetic of the external passive layer formation based on Mo This effect is also visible in the study of El Hajjaji et al. after cathodic reduction of the passive layer. $^{14}$

After 20 hours exposure time in phosphoric acid at RT, the temperature was continuously increased with a heating rate of $1{ }^{\circ} \mathrm{C} \mathrm{min}-1$ within two hours and subsequently held for another two hours at $130^{\circ} \mathrm{C}$. This allows the investigation of the dynamic depletion of passive layers as a function of temperature, as shown in Figure 4. The rectangles in the diagrams describe the measured temperature with a temperature deviation of $\pm 5^{\circ} \mathrm{C}$. The decline of passivation starts already at $40^{\circ} \mathrm{C}$ and is accelerated when going beyond $80^{\circ} \mathrm{C}$. Considering stainless steels in Figure 4a, material 1.4301, which has the highest amount of $\mathrm{Fe}$ and no additional metals except $\mathrm{Cr}(18 \%)$ and $\mathrm{Ni}(10 \%)$, possesses the lowest stability with potential plateaus at $65 \mathrm{mV}, 0 \mathrm{mV}$ and finally- $45 \mathrm{mV}$. This stepwise potential drop at $130^{\circ} \mathrm{C}$ illustrates clearly the time dependent degradation of passive layers with their variable composition. 1.4404 with $2 \%$ Mo and 1.4571 with $1 \%$ Ti show a similar two-step potential drop with a constant value of $25 \mathrm{mV}$ after four hours. $1.4372(7 \% \mathrm{Mn})$ achieves the highest $\mathrm{E}_{\text {cor }}$ with a final corrosion potential of $50 \mathrm{mV}$. $\mathrm{E}_{\text {cor }}$ in the range $-25-50 \mathrm{mV}$ corresponds to first step in Figure 3 that can be attributed to existence of $\mathrm{Cr}_{2} \mathrm{O}_{3}$. This is in agreement with the results of Wang and Turner. ${ }^{25}$ Additional experiments with different heating rates showed varying negative slopes of $\mathrm{E}_{\mathrm{cor}}$. This leads to the conclusion, that the depletion of the external passive layer is thermodynamic controlled, whereas the degradation of the internal protection layer is rather a kinetic process.

By comparing the development of $\mathrm{E}_{\mathrm{cor}}$ of Ni-based alloys, shown in Figure $4 \mathrm{~b}$, the most promising alloys in terms of passive layer stability at $130^{\circ} \mathrm{C}$ are 2.4869 and 2.4819 . In the time range $0.5-1.5 \mathrm{~h}, \mathrm{E}_{\text {cor }}$ of $2.4869(80 \% \mathrm{Ni})$ decreases to $300 \mathrm{mV}$ and rises afterwards slowly to a constant value of $380 \mathrm{mV}$ until the end of measurement. Material 2.4819 with $57 \% \mathrm{Ni}, 16 \%$ Mo and $4 \% \mathrm{~W}$ has a stable corrosion potential of $335 \mathrm{mV}$ after four hours. For comparison, alloy 625 (2.4856), which contains also approx. 60\% Ni and additional support of $9 \%$ Mo and $4 \% \mathrm{Nb}$, ends with a significantly lower potential of $95 \mathrm{mV}$. However, sample 2.4733 including $57 \% \mathrm{Ni}$ and even $14 \% \mathrm{~W}$, but only $2 \%$ Mo exhibits an $\mathrm{E}_{\text {cor }}$ of $65 \mathrm{mV}$. Thus, it can be stated that besides Ni also an enhanced content of Mo is necessary for a high $\mathrm{E}_{\mathrm{cor}}$. The free corrosion potential $\mathrm{E}_{\mathrm{cor}}$ increases with rising content of Mo (shown in Table II). Further, material 904L (1.4539) with 5\% Mo and $2 \% \mathrm{Cu}$ shows a final value around $65 \mathrm{mV} .1 .4876$ with $\sim 1 \% \mathrm{Ti} / \mathrm{Al}$ and without Mo exhibits the lowest $\mathrm{E}_{\mathrm{cor}}$ of $\sim 10 \mathrm{mV}$.

The study of the free corrosion potential represents the formation and the temperature dependent depletion of passive layers without polarization. As conclusion it can be figured out, that for corrosion resistivity of metals a low iron and a high nickel content in alloys is inevitable to protect the subjacent metal from oxidation. Beside this, the additional support of Mo is beneficial for thermodynamically

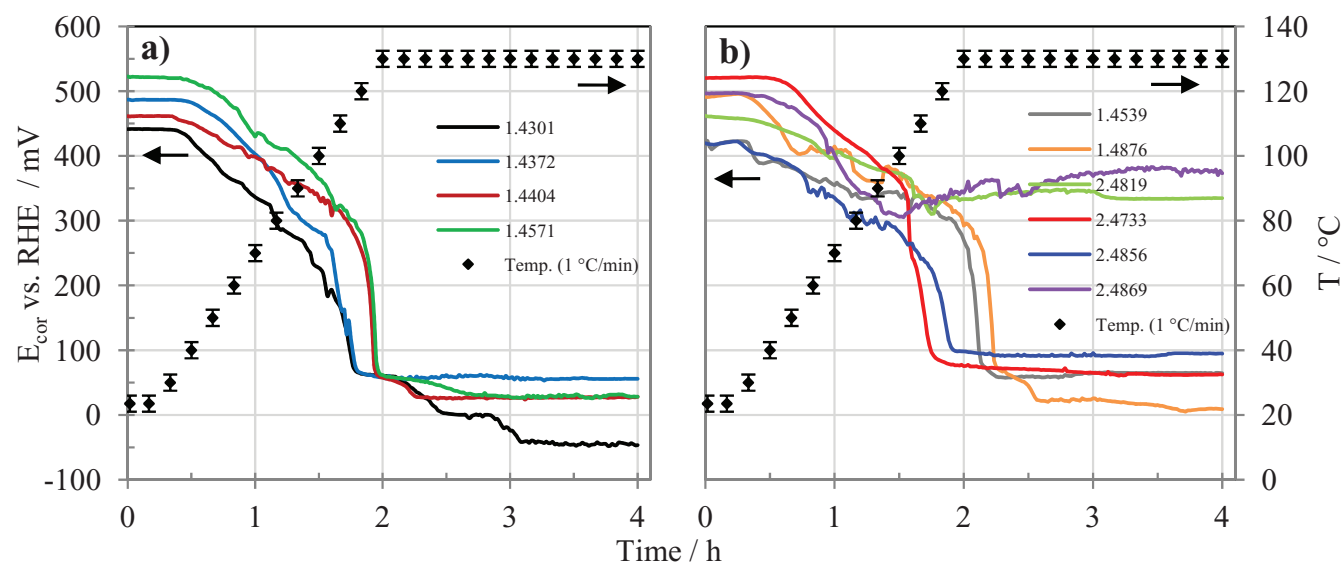

Figure 4. Progress of $\mathrm{E}_{\text {cor }}$ of metallic materials measured in $85 \mathrm{wt} \% \mathrm{H}_{3} \mathrm{PO}_{4}$ at elevated temperature for $\left.4 \mathrm{~h}: \mathrm{a}\right)$ Austenitic stainless steels and b) Ni-based alloys. 


\section{Table II. Correlation between content of Mo and $\mathrm{E}_{\text {cor }}$ of Ni-based} alloys at $130^{\circ} \mathrm{C}$. Values taken from Figure $4 \mathrm{~b}$.

\begin{tabular}{ccc} 
Material & Content Mo /wt $\%$ & $\mathrm{E}_{\text {cor }} / \mathrm{mV}$ \\
\hline 1.4876 & 0 & 9 \\
1.4539 & 5 & 65 \\
2.4856 & 9 & 95 \\
2.4819 & 16 & 335
\end{tabular}

stable passivation. Indeed, even $1 \%$ of Ti support possesses favorable passivation with $\mathrm{E}_{\text {cor }}$ over $500 \mathrm{mV}$ at RT, but these passive layers are demonstrated to be not stable at elevated temperatures. Additions of $\mathrm{Mn}, \mathrm{Al}, \mathrm{Cu}$ and $\mathrm{Nb}$ have shown no enhancement of $\mathrm{E}_{\mathrm{cor}}$ at $130^{\circ} \mathrm{C}$. The free corrosion potential is the state when no potential is applied to the samples. In terms of fuel cell application this corresponds to a switched-off condition. An operating hydrogen/air HT-PEFC has nearly $0 \mathrm{~V}$ at the anodic and about $0.6 \mathrm{~V}$ at the cathodic compartment at typical operating conditions. In the open-circuit mode (OCV) a potential difference of $0.95 \mathrm{~V}$ between anode and cathode can be measured. In the following section, the behavior of metals and their passivation under polarization is going to be considered.

Cyclic voltammetry - dynamic formation of passive layers. - In order to use customary and low priced metallic materials as bipolar plates for HT-PEFCs it is unavoidable to understand the passivation process in phosphoric acid also under polarization. Potentiodynamic voltammetry was performed to investigate the role of alloying elements on its passivation properties, which is associated with an oxidation peak in the prepassive region when applying anodic potential. Typical voltammograms for austenitic stainless steels and Ni-based

\section{Table III. Correlation between content of Mo and maximum} current $j_{\mathrm{CV}}$ / charge $\mathrm{Q}_{\mathrm{CV}}$ of oxidation peak of Ni-based alloys at RT. Values taken from Figure 5b and Figure 7.

\begin{tabular}{cccc} 
Material & Content Mo $/ \mathrm{wt} \%$ & $\mathrm{j} \mathrm{CV} / \mathrm{mA} \mathrm{cm}^{-2}$ & $\mathrm{Q}_{\mathrm{CV}} / \mathrm{mC} \mathrm{cm}^{-2}$ \\
\hline 1.4876 & 0 & 0.38 & 0.98 \\
1.4539 & 5 & 0.66 & 2.81 \\
2.4856 & 9 & 1.53 & 5.48 \\
2.4819 & 16 & 1.83 & 7.68
\end{tabular}

alloys at RT with a scan rate of $100 \mathrm{mV} \mathrm{s}^{-1}$ are shown in Figure 5a, $5 \mathrm{~b}$. For reasons of comparability only the tenth cycle is given in the diagrams, respectively. Material 304 (1.4301), as the simplest stainless steel, indicates a maximum current density of $135 \mu \mathrm{A} \mathrm{cm}^{-2}$ at $0.6 \mathrm{~V}$ in the prepassive state. Afterwards the current decreases down to $80 \mu \mathrm{A} \mathrm{cm}^{-2}$ due to passivity and rises again in the transpassive region rapidly (see Figure 5a). It is conspicuous that stainless steels 1.4404 and 1.4571 with slightly more Ni content (12\%) and in addition $2 \%$ Mo reveal larger oxidation peaks with a current density of $360 \mu \mathrm{A} \mathrm{cm}^{-2}$ at maximum. This effect is also confirmed by sample 1.4372, which implies only $5 \% \mathrm{Ni}$ and no Mo and accordingly induces a minor current of $93 \mu \mathrm{A} \mathrm{cm}^{-2}$ at peak maximum. The reduction peak of released metal ions in solution within the backscan cannot be detected due to continuous agitation during the measurements. The reduction of corresponding passive layers takes place at negative polarization simultaneously with hydrogen evolution in the cathodic range.

Regarding Ni-based alloys (Figure 5b), three main trends can be observed quite distinctly. First, analogous to stainless steels above, the more Mo included in the alloy the higher the maximum current densities. From Table III it can be referred that the anodic current $\mathrm{j}_{\mathrm{cv}}$ at peak maximum as well as the integrated charge $\mathrm{Q}_{\mathrm{cv}}$ of the
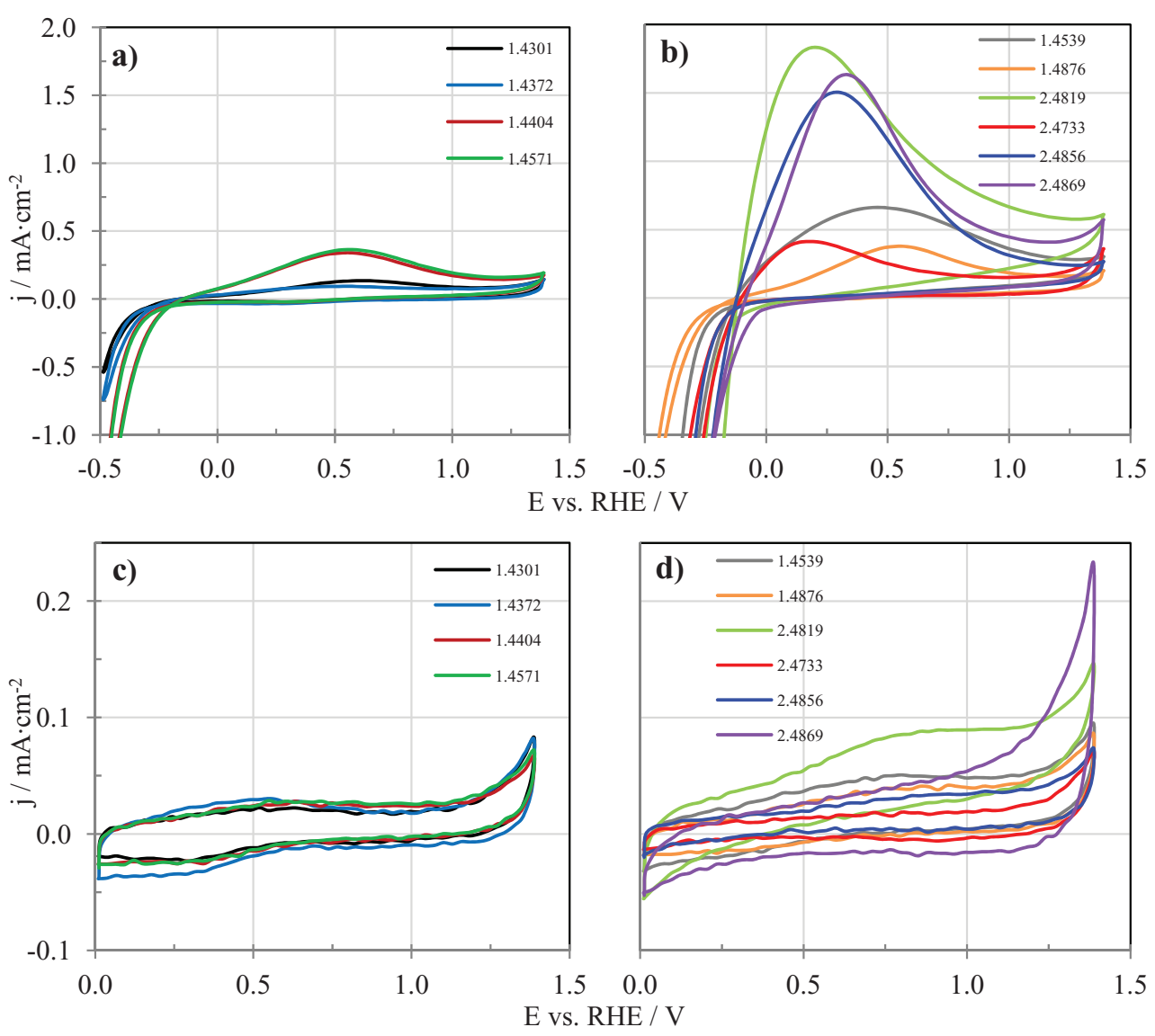

Figure 5. Cyclic voltammograms measured in $85 \mathrm{wt} \% \mathrm{H}_{3} \mathrm{PO}_{4}$ at $\mathrm{RT}$ with the scan rate $100 \mathrm{mV} \mathrm{s}^{-1}$ : a) Austenitic stainless steels and b) Ni-based alloys in the potential range $-0.5-1.4 \mathrm{~V}$ and c) Austenitic stainless steels and d) Ni-based alloys in the potential range 0-1.4 $\mathrm{V}$. 

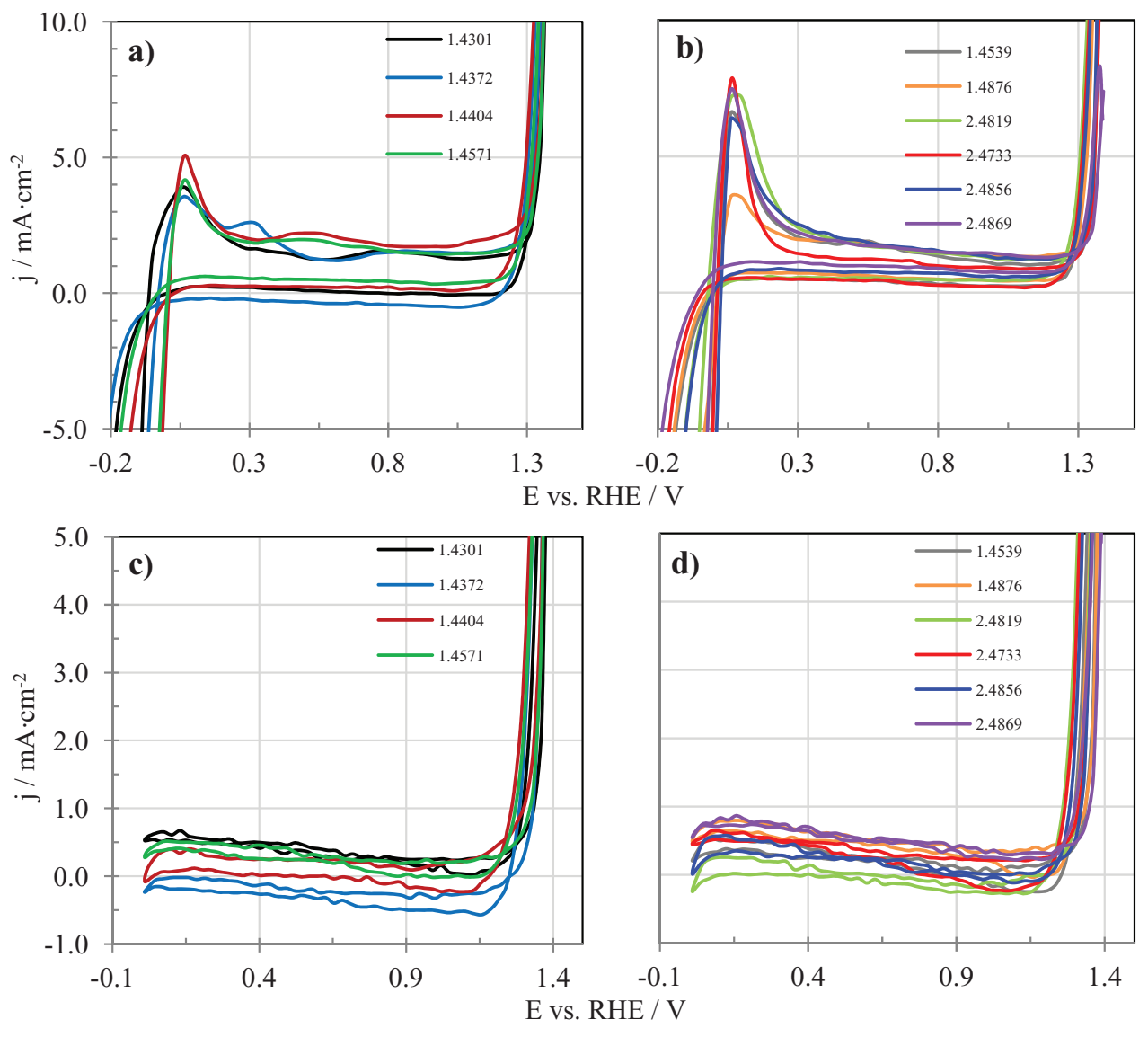

Figure 6. Cyclic voltammograms measured in $85 \mathrm{wt} \% \mathrm{H}_{3} \mathrm{PO}_{4}$ at $130^{\circ} \mathrm{C}$ with the scan rate $100 \mathrm{mV} \mathrm{s}^{-1}$ : a) Austenitic stainless steels and b) Ni-based alloys in the potential range $-0.5-1.4 \mathrm{~V}$ and c) Austenitic stainless steels and d) Ni-based alloys in the potential range 0-1.4 V.

oxidation peaks increases with growing amount of Mo. Second aspect is the apparent shift of the oxidation peak maximum to less noble values from $550 \mathrm{mV}$ (1.4876) to $175 \mathrm{mV}$ (2.4819) with enhancing Mo content. Noticeable is also the impact of $\mathrm{W}$ on the position of the oxidation peak. Both W-alloyed materials 2.4819 and 2.733 exhibit a shift of the peak maximum to $175 \mathrm{mV}$. And the third effect is influence of $\mathrm{Ni}$ on the anodic oxidation. The more $\mathrm{Ni}$ included in the alloy the higher the maximal anodic current densities. This seems to be reasonable, since $\mathrm{Ni}$-ions have to be released out of the metal first before they build up a passive layer on the metal surface. Therefore, the relatively high currents of the oxidation peaks derive from the initial Ni dissolution that diminishes strongly after passivation. Steady state analyses below are going to verify this effect. Sample 2.4869 with $80 \%$ nickel has an oxidation current of $1.63 \mathrm{~mA} \mathrm{~cm}^{-2}$, which is more than one magnitude higher than that of stainless steel 1.4301 or fivefold higher than in the case of 1.4404 . This potentiodynamic study also allows concluding, that there is no positive effect of addings like Ti and $\mathrm{Mn}$ in stainless steels and $\mathrm{Nb}, \mathrm{Cu}$ and $\mathrm{W}$ concerning Ni-based alloys at RT. Probably the current peaks of Ni and Mo overlap all other peaks, as they are broad and dominant.

Under normal fuel cell operation, there is fortunately no negative potential, which may cause reduction of the protective passive layers. Hence, the dynamic voltammetry was also carried out in the potential window 0-1.4 V with remarkable results, see Figure 5c, 5d. For both stainless steels and Ni-based alloys the anodic current in the prepassive region (oxidation peak) could be mitigated clearly, because the passive layers are stable in this potential window. In case of stainless steels a mitigation of the oxidation peak maximum from $360 \mu \mathrm{A} \mathrm{cm}^{-2}$ to $23 \mu \mathrm{A} \mathrm{cm}^{-2}$ at $0.5 \mathrm{~V}$ was possible and concerning the alloys below $100 \mu \mathrm{A} \mathrm{cm}^{-2}$ depending on the material. At these experimental conditions material 2.4733 turns out to be the candidate with the lowest anodic current density of $\sim 15 \mu \mathrm{A} \mathrm{cm}^{-2}$. Now the protective influence of W-oxide turns out to be noticeable.

Comparing these results with measurements at $130^{\circ} \mathrm{C}$, which are more realistic for the HT-PEFC environment, it can be observed that the oxidation current increases considerably at elevated temperature. Concerning stainless steels in Figure 6a, the max. current densities of the oxidation peaks are between $3.5-5.0 \mathrm{~mA} \mathrm{~cm}{ }^{-2}$, which corresponds to a current increase of more than one order of magnitude than at RT. In the case of Ni-based alloys the already known trend can be reflected again. Alloy 1.4876 without Mo shows a relatively low oxidation current of $3.5 \mathrm{~mA} \mathrm{~cm}{ }^{-2}$, which is also one magnitude higher than at RT. The other alloys either with Mo or with a very high amount of $\mathrm{Ni}$ reveal a current rise up to $6.4-7.8 \mathrm{~mA} \mathrm{~cm}^{-2}$, shown in Figure $6 \mathrm{~b}$. These values are roughly four times higher than those at RT. Additionally, the position of the oxidation peaks moved from $170-550 \mathrm{mV}$ to $50 \mathrm{mV}$ and the width became smaller. In the passive region $0.3-1.2 \mathrm{~V}$ the anodic current is between $0.7-2.2 \mathrm{~mA} \mathrm{~cm}^{-2}$ for both stainless steels and Ni-based alloys, whereas in the case of stainless steels there are some small peaks, which show an oxidation of the containing elements and the formation of their passive layers. In terms of the alloys in Figure $6 \mathrm{~b}$ the current declines linearly with increasing potential until the beginning of oxygen evolution at nearly 1.2 V. 2.4733 with $14 \%$ W figures out to be again the best material with the fastest passivation and the lowest corrosion current in the passive range. This decline of the passive current densities indicates a dense outer passive film formation based on the high amount of $\mathrm{Ni}$ and $\mathrm{W}$. An improvement of the corrosion resistivity by the elements $\mathrm{Mo}, \mathrm{Mn}, \mathrm{Ti}, \mathrm{Cu}$, and $\mathrm{Nb}$ could not be observed at $130^{\circ} \mathrm{C}$. As for the measurements at RT, the extended oxidation peaks of $\mathrm{Ni}$ and Mo seem to mask all other peaks.

Figure 7 illustrates the integrated anodic current of the oxidation peaks in the cyclic voltammograms (Figure 5a, $5 \mathrm{~b}$ and Figure 6a, 6b), 


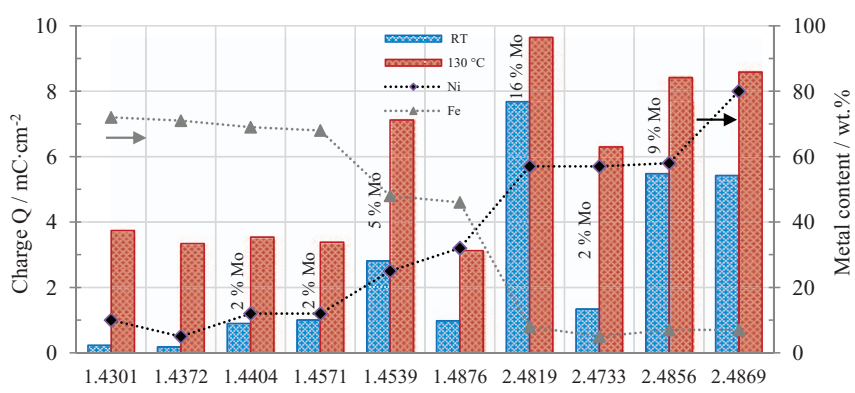

Figure 7. Charge calculated from oxidation peaks in Figure 5a/5b and Figure $6 a / 6 b$.

which correspond to the charge of the dissolved metal ions. As already discussed above, the relatively high charge derives from an increasing content of $\mathrm{Ni}$ and Mo. Materials with no/low support of Mo and a moderate amount of $\mathrm{Ni}(<30 \%)$ show the lowest charge at RT and $130^{\circ} \mathrm{C}$. However, the rise of the amount of dissolved metal species rises at $130^{\circ} \mathrm{C}$ severely, especially for stainless steel without Mo. The role of anodic oxidation peak and the current density in the passive region are going to be discussed in quasi potentiostatic measurements below.

When avoiding negative potentials, the oxidation peak around $50 \mathrm{mV}$ in the cyclic voltammograms of stainless steels and Ni-based alloys (Figure 6c, 6d) disappears and the anodic current density in the potential window $0.3-1.2 \mathrm{~V}$ decreases distinctly. Due to the high scan rate of $100 \mathrm{mV} \mathrm{s}^{-1}$, there is a high deviation of the anodic and cathodic sweeps. An decline of the anodic current of $\sim 0.75 \mathrm{~mA} \mathrm{~cm}^{-2}$ at the beginning at $0 \mathrm{~V}$ and $\sim 0.2 \mathrm{~mA} \mathrm{~cm}^{-2}$ at $1.2 \mathrm{~V}$ without any oxidation peaks demonstrates an obvious improvement of the passive layer stability by one order of magnitude in comparison to voltammetry starting at $-0.5 \mathrm{~V}$. Hence, in order to maintain stable passivation negative disruptive potentials with its reducing effect should be avoided. Considering these examined materials in an operating fuel cell, it comes out that the anodic bipolar plate (at $0 \mathrm{~V}$ ) would corrode even faster than the cathodic bipolar plate at $0.6 \mathrm{~V}$ (operating conditions) and $\sim 0.95 \mathrm{~V}$ (OCV mode). Of course, this is only a rough estimation, which neglects the additional oxygen corrosion in the cathode compartment.

Steady state polarization - constraints of the natural passivation.By means of cyclic voltammetry, the dynamic formation and reduction of passive layers was examined in order to get more fundamental information about rate, reproducibility and cycle stability of passivation in a potential range. However, for more realistic fuel cell application, steady-state polarization was accomplished under an absolute current tolerance of $10 \mathrm{nA} \mathrm{s}^{-1}$. Figure 8 shows cathodic and anodic corrosion current densities of all examined materials as Tafel plots measured in $85 \mathrm{wt} \% \mathrm{H}_{3} \mathrm{PO}_{4}$ at RT. The free corrosion potential $\mathrm{E}_{\mathrm{cor}}$ and the partial current density $\mathrm{j}_{\text {cor }}$ of respective material were also determined. The potential windows were $-0.5 \mathrm{~V}-2.0 \mathrm{~V}$ (see Figure $8 \mathrm{a}, 8 \mathrm{~b}$ ) and $0-1.0$ $\mathrm{V}$ (Figure 8c, 8d) measured against RHE in $1 \mathrm{M} \mathrm{H}_{3} \mathrm{PO}_{4}$.

Tafel plots of stainless steels at RT (Figure 8a) reveal that 1.4301 and 1.4372 as well as 1.4404 and 1.4571 have comparable curves with similar values for $\mathrm{E}_{\mathrm{cor}}$ and $\mathrm{j}_{\mathrm{cor}}$. These results correspond to their similar composition. An overview of all values is given in Table IV. The free corrosion potential $\mathrm{E}_{\mathrm{cor}}$ describes the mixed potential of the metal as discussed above. In case of a homogeneous metal surface it
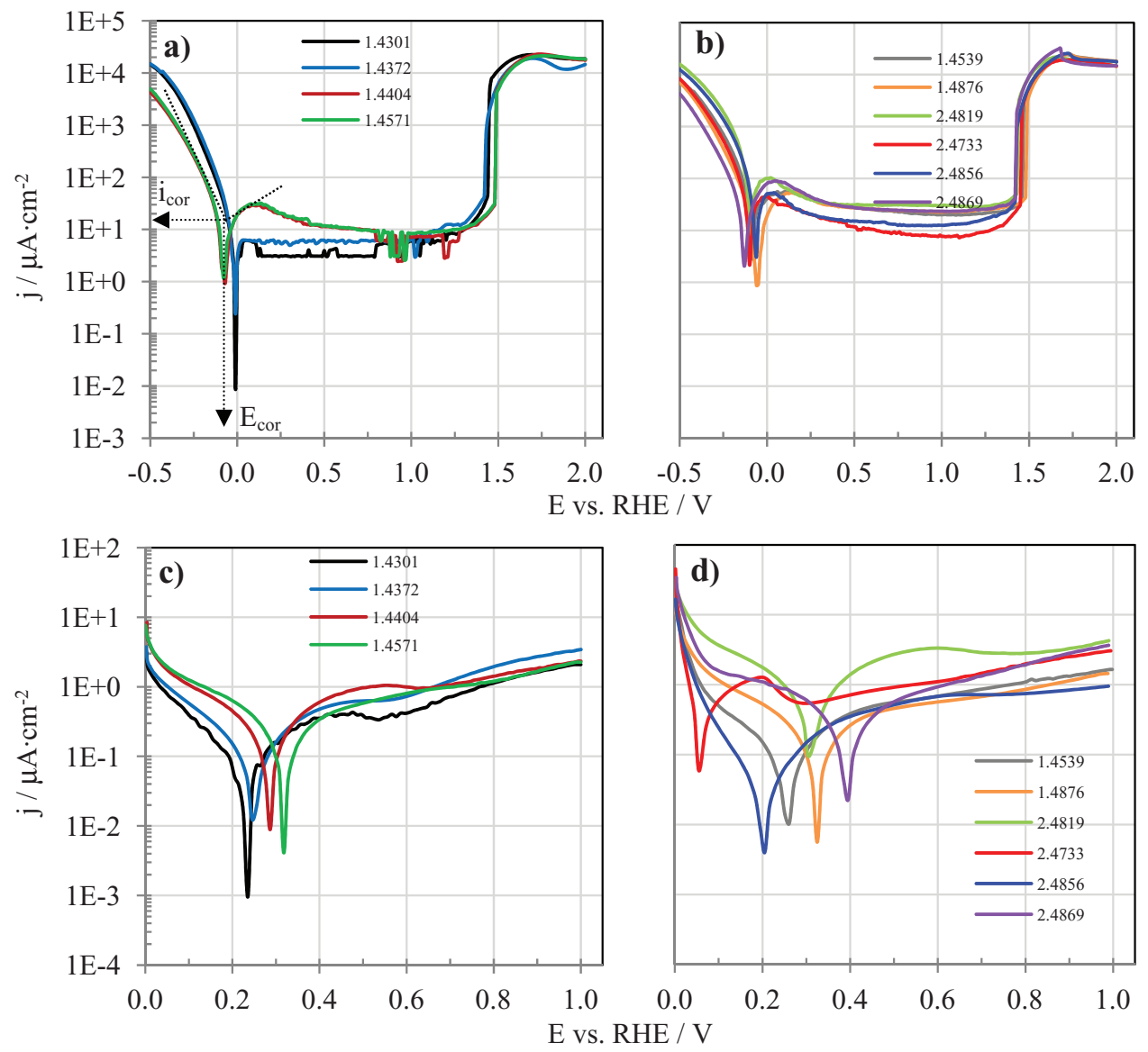

Figure 8. Tafel plots measured in $85 \mathrm{wt} \% \mathrm{H}_{3} \mathrm{PO}_{4}$ at RT: a) Austenitic stainless steels and b) Ni-based alloys in the potential range $-0.5 \mathrm{~V}-2.0 \mathrm{~V}$. c) Austenitic stainless steels and d) Ni-based alloys in the positive potential range $0 \mathrm{~V}-1.0 \mathrm{~V}$. 
Table IV. Calculated values for $\mathbf{E}_{\text {cor }}$ and $\mathbf{j}_{\mathrm{cor}}$ at RT from Figure 8.

\begin{tabular}{cccccr} 
& \multicolumn{2}{c}{$\mathrm{E}_{\mathrm{cor}} / \mathrm{mV}$} & & \multicolumn{2}{c}{$\mathrm{j}_{\mathrm{cor}} / \mu \mathrm{A} \mathrm{cm}^{-2}$} \\
\cline { 2 - 3 } Material & $-0.5-2.0 \mathrm{~V}$ & $0-1.0 \mathrm{~V}$ & & $-0.5-2.0 \mathrm{~V}$ & $0-1.0 \mathrm{~V}$ \\
\hline 1.4301 & -12 & 235 & & 5.23 & 0.07 \\
1.4372 & -15 & 245 & & 5.89 & 0.10 \\
1.4404 & -88 & 287 & & 22.75 & 0.30 \\
1.4571 & -88 & 318 & & 22.75 & 0.29 \\
1.4539 & -72 & 261 & & 25.43 & 0.11 \\
1.4876 & -74 & 325 & & 19.81 & 0.19 \\
2.4819 & -60 & 305 & & 56.60 & 0.53 \\
2.4733 & -108 & 54 & & 30.34 & 0.34 \\
2.4856 & -58 & 205 & & 38.51 & 0.04 \\
2.4869 & -124 & 381 & & 40.87 & 0.31
\end{tabular}

is the theoretical potential, at which the anodic branch (dissolution of metal) and the cathodic branch (reduction of passive layer/generation of $\mathrm{H}_{2}$ ) have the same absolute values for $\mathrm{j}_{\text {cor }}$. Basically, the anodic branches are of interest, which figure out the passivation in the potential range between $0.2 \mathrm{~V}$ and $1.2 \mathrm{~V}$ and the transpassive state beyond $1.2 \mathrm{~V}$, where one cannot distinguish between metal dissolution and oxygen evolution. The fluctuations of current between $0.8 \mathrm{~V}$ and $1.3 \mathrm{~V}$ predict local corrosion or the upcoming perforation of the passive layers caused by Fe corrosion. The cathodic branches with a negative slope at potentials less than $0 \mathrm{~V}$, which usually do not occur in fuel cells, show merely the reduction reaction $\left(\mathrm{H}_{2}\right.$ formation coupled with passive layer reduction). Comparing 1.4301 and 1.4372 , there is no noteworthy improvement due to the addition of $7 \% \mathrm{Mn}$. This is in agreement with the results of Pardo et al., who reported that $\mathrm{Mn}$ in 1.4372 does not form insoluble oxides. ${ }^{33,34}$ When considering 1.4404 and 1.4571, a beneficial effect of Ti cannot be observed, either. The partial current density $\mathrm{j}_{\text {cor }}$ (current at $\mathrm{E}_{\mathrm{cor}}$ ) is $\sim 5 \mu \mathrm{A} \mathrm{cm}^{-2}$ regarding 1.4301/1.4372 and $23 \mu \mathrm{A} \mathrm{cm}-2$ for 1.4404/1.4571. Surprisingly, the lowest corrosion current densities at RT can be attributed to common steels 1.4301 and 1.4372. In the passive region stainless steels show corrosion rates of $3 \mu \mathrm{A} \mathrm{cm}^{-2}$ (1.4301) and $12 \mu \mathrm{A} \mathrm{cm}^{-2}$ (1.4571).

In comparison, the corrosion currents of the alloys (Figure 8b) are higher at RT. For instance, material 2.4733 as the best Ni-based alloy shows a threefold current density $\left(10 \mu \mathrm{A} \mathrm{cm}^{-2}\right)$ at $0.6 \mathrm{~V}$ compared to 1.4301. This allows the conclusion that Fe makes an advantageous contribution to passivation, at least at RT. Further Ni-based alloys do not exhibit fluctuations in the potential window $0.8-1.2 \mathrm{~V}$. $\mathrm{E}_{\mathrm{cor}}$ is in the same range, whereas $\mathrm{j}_{\text {cor }}$ is slightly higher as those of stainless steels, shown in Table IV.

Since polarization below $0 \mathrm{~V}$ induces passive layer reduction as a side reaction to generation of $\mathrm{H}_{2}$ and because negative potentials are not an issue in operating fuel cells, the investigations were performed starting from $0 \mathrm{~V}$ and ending at $1.0 \mathrm{~V}$ (see Figure 8c, 8d). Two effects are immediately evident. Firstly, $\mathrm{E}_{\mathrm{cor}}$ of stainless steels and alloys shifts from about $0 \mathrm{~V}$ to more noble values of up to $0.4 \mathrm{~V}$. Indeed, the values for $\mathrm{E}_{\text {cor }}$ are lower than ascertained in Figure 3, because the reducing current that is proceeding in the cathodic branch from $0 \mathrm{~V}$ to $\mathrm{E}_{\text {cor }}$ weakens the passive layer partially and leads to lower values of $\mathrm{E}_{\text {cor }}$ compared to those observed currentless in Figure 3. But nevertheless the same trend is visible, namely the presence of small amounts of $\mathrm{TiC}$ in materials 1.4571 and 1.4876 and a high amount of $\mathrm{Ni}$ (2.4869) result in the highest values for $\mathrm{E}_{\mathrm{cor}}$ (318$381 \mathrm{mV}$, see Table IV). Secondly, corrosion rates decrease distinctly once beginning polarization at $0 \mathrm{~V}$ compared to starting at $-0.5 \mathrm{~V}$. Concerning material 1.4301 , the anodic current density diminishes by one order of magnitude to $0.41 \mu \mathrm{A} \mathrm{cm} \mathrm{cm}^{-2}$ at $0.6 \mathrm{~V}$. The partial current density $\mathrm{j}_{\text {cor }}$ even drops down to $0.07 \mu \mathrm{A} \mathrm{cm}^{-2}$. The best Nibased alloys are $1.4876,1.4539$ and 2.4856 with values of $0.56-0.68$ $\mu \mathrm{A} \mathrm{cm}^{-2}$ at $0.6 \mathrm{~V}$ and $0.04-0.19 \mu \mathrm{A} \mathrm{cm}^{-2}$ at $\mathrm{E}_{\mathrm{cor}}$. Material 2.4819 with $16 \%$ Mo and $4 \% \mathrm{~W}$ shows the worst corrosion resistance. Once exceeding potentials of $0.5 \mathrm{~V}$, the current density first decreases due to passivation, as expected, and rises afterwards in the case of stainless steels. In contrast, the slope of the anodic branch of alloys is quite linear (except 2.4819) and runs most steeply for Cronix 80. Material 2.4856 exhibits the smallest slope of the anodic branch and the lowest current densities in the range $0.7-1.0 \mathrm{~V}$ and at $\mathrm{E}_{\mathrm{cor}}$. At $1.0 \mathrm{~V}$ the corrosion currents of stainless steels and alloys are still one order of magnitude lower than in the case of polarization starting at $-0.5 \mathrm{~V}$. Hence, the applied potential is an important factor in order to reduce the corrosion current. By eliminating cathodic polarization, the passive layer protects the subjacent metal from corrosion.

Again, to approach more realistic HT-PEM conditions, steady-state measurements were also carried out at $130^{\circ} \mathrm{C}$. Figure 9 shows Tafel plots measured at $130^{\circ} \mathrm{C}$ in an analogous way as above in the potential range $-0.5-1.4 \mathrm{~V}$ and accordingly $0-1.0 \mathrm{~V}$. The upper potential was adjusted to $1.4 \mathrm{~V}$ to prevent resulting anodic currents exceeding 1 A. Regarding the behavior of stainless steels shown in Figure 9a, the $\mathrm{E}_{\mathrm{cor}}$ values of little more than $0 \mathrm{~V}$ at $130^{\circ} \mathrm{C}$ are comparable with those obtained at RT. However, they are slightly different to those presented in Figure $4 \mathrm{a}$, where $\mathrm{E}_{\mathrm{cor}}$ of material 1.4301 decreases in three potential steps down to $-45 \mathrm{mV}$ after four hours at $130^{\circ} \mathrm{C}$. The last kinetic controlled step from $0 \mathrm{~V}$ to $-45 \mathrm{~V}$, which occurred after three hours, seems to be more stable and apparently demands more time. Concerning Ni-based alloys in Figure $9 \mathrm{~b}, \mathrm{E}_{\mathrm{cor}}$ is also located around $0 \mathrm{~V}$ for all materials, even in the case of 2.4819 and 2.4869, which reveal the highest corrosion potentials after four hours at $130^{\circ} \mathrm{C}$ in Figure $4 \mathrm{~b}$. These results derive from the harsh reduction of the passive layers during cathodic polarization beginning at $-0.5 \mathrm{~V}$. A summary of all corrosion potentials and partial current densities at $130^{\circ} \mathrm{C}$ is given in Table V. Anodic corrosion currents at $130^{\circ} \mathrm{C}$ turn out to be in the range of $35-200 \mu \mathrm{A} \mathrm{cm}^{-2}$ at $0.6 \mathrm{~V}$, which is roughly one order of magnitude higher than in the same potential window at RT. 1.4301 (in group of stainless steels) and 2.4869 (in category Ni-based alloys) emerged to be the best candidates with passive current densities of $67 \mu \mathrm{A} \mathrm{cm}^{-2}$ and $33 \mu \mathrm{A} \mathrm{cm}^{-2}$ at $0.6 \mathrm{~V}$. However, Cronix 80 (2.4869) provides an extraordinary high partial current density $\mathrm{j}_{\text {cor }}$ of $8880 \mu \mathrm{Acm}^{-2}$ that can be explained by a high ratio of nickel oxidation in order to build up a protective passive layer. This strong passivation leads in the following potential window of $0.2-1.2 \mathrm{~V}$ to a sharp decrease of the corrosion current down to $33 \mu \mathrm{A} \mathrm{cm}^{-2}$. The worst corrosion resistance can be figured out for alloy 1.4876, which is determined to be $200 \mu \mathrm{A} \mathrm{cm}^{-2}$ in the passive region.

Finally steady-state analyses were carried out by circumventing cathodic polarization, which reducing condition turns out to be very disruptive for passive films (see Figure 9c, 9d). This procedure leads to more positive values for $\mathrm{E}_{\mathrm{cor}}$, especially concerning Cronix 80 (shift from -73 to $235 \mathrm{mV}$ ). Further, the higher starting potential leads to a significant current drop: at $\mathrm{E}_{\mathrm{cor}}$ from $8881 \mu \mathrm{A} \mathrm{cm} \mathrm{cm}^{-2}$ to $0.7 \mu \mathrm{A}$ $\mathrm{cm}^{-2}$, at $0.35 \mathrm{~V}$ from $31.5 \mu \mathrm{A} \mathrm{cm}^{-2}$ to $3.6 \mu \mathrm{A} \mathrm{cm}^{-2}$, at $0.6 \mathrm{~V}$ from $34.6 \mu \mathrm{A} \mathrm{cm}^{-2}$ to $16.1 \mu \mathrm{A} \mathrm{cm}^{-2}$ and at $1.0 \mathrm{~V}$ from $40.9 \mu \mathrm{A} \mathrm{cm}^{-2}$ to $26.7 \mu \mathrm{A} \mathrm{cm}^{-2}$. The passive current densities of the remaining materials are in the range from 25 to $100 \mu \mathrm{A} \mathrm{cm}^{-2}$. The noticeable current maximum around $100 \mathrm{mV}$ in the anodic branch regarding samples 1.4571 and 1.4876 indicates significant Ti corrosion before formation of passive layers with proceeding anodic polarization, keeping in mind that this is quite near to the potential of the anodic bipolar plate in the fuel cell. This initial corrosion of material 1.4876 reaches a maximum level of $770 \mu \mathrm{A} \mathrm{cm}^{-2}$ at $130 \mathrm{mV}$.

Besides Cronix 80, all other samples exhibit similar current densities in the range of $25-100 \mu \mathrm{Acm}^{-2}$ in the passive range beyond $300 \mathrm{mV}$ in Figure 9c, 9d. Consequently, we could verify that in fact $\mathrm{Cr}$ is mainly responsible for passivation since all tested materials have a Cr content of $17-22 \%$. Secondary, a high amount of $\mathrm{Ni}(\sim 80 \%)$ provides an additional protection against corrosion. This insights confirm the model of an dense inner $\mathrm{Cr}_{2} \mathrm{O}_{3}$ and an porous outer $\mathrm{Ni}_{3}\left(\mathrm{PO}_{4}\right)_{2}$ layer. A positive effect of Mo on passivity could not be observed. Quite the contrary, at RT as well as at $130^{\circ} \mathrm{C}$ samples with Mo show elevated corrosion densities. For instance, 2.4733 with $16 \%$ Mo depicts an increase of current above $300 \mathrm{mV}$ at $130^{\circ} \mathrm{C}$. This potential is typical for dissolution of Mo in Mo-richt alloys at elevated temperatures. ${ }^{35} \mathrm{~A}$ beneficial influence of $\mathrm{W}, \mathrm{Nb}$ and $\mathrm{Cu}$ could also not be demonstrated obviously at $130^{\circ} \mathrm{C}$. Moreover, Ti support leads to enhanced passive 

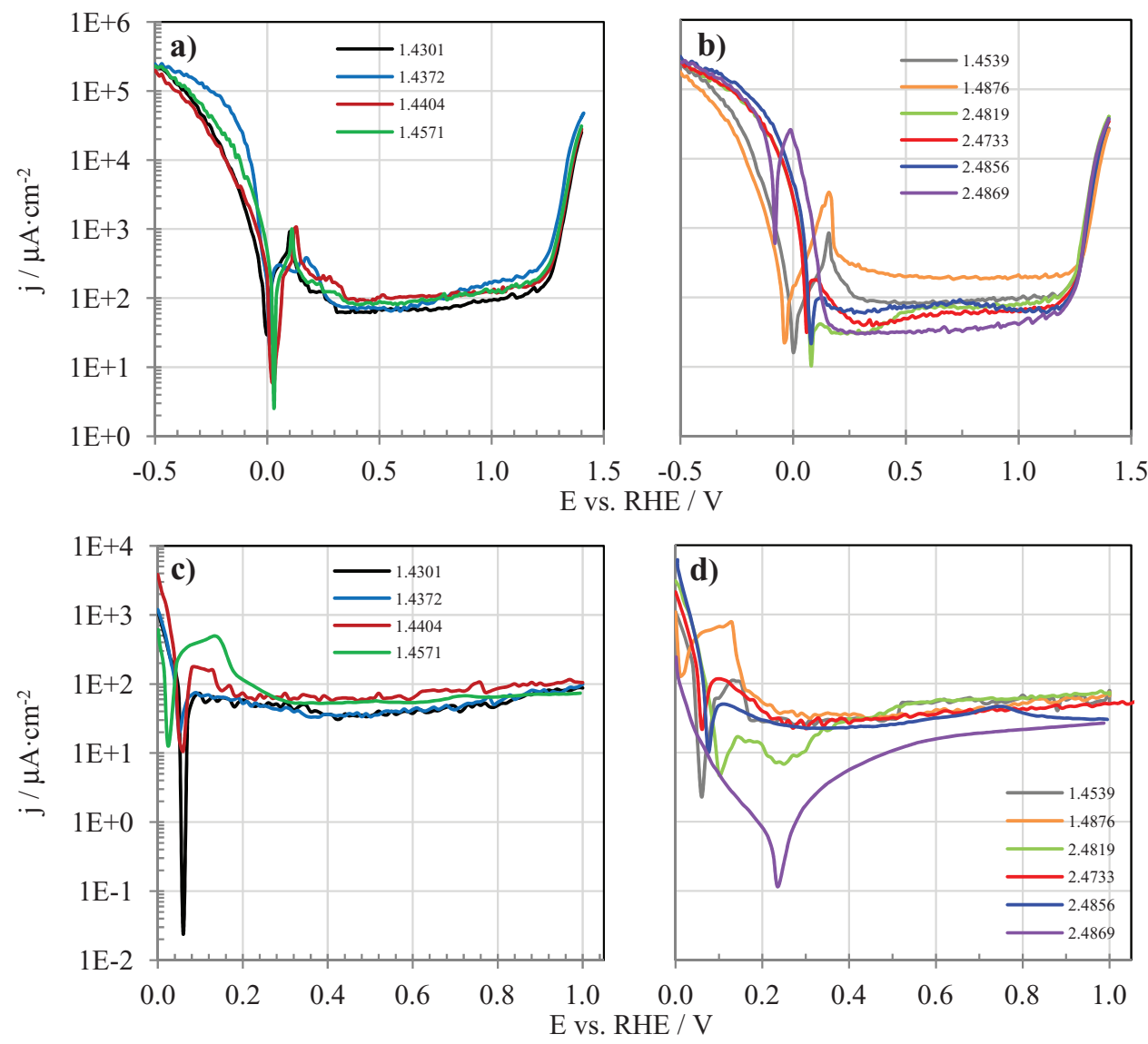

Figure 9. Tafel plots measured in $85 \mathrm{wt} \% \mathrm{H}_{3} \mathrm{PO}_{4}$ at $130^{\circ} \mathrm{C}$ : a) Austenitic stainless steels and b) Ni-based alloys in the potential range $-0.5 \mathrm{~V}-1.4 \mathrm{~V}$. c) Austenitic stainless steels and d) Ni-based alloys in the positive potential range $0 \mathrm{~V}-1.0 \mathrm{~V}$.

current densities, which is inferred from fragile Ti-based passivation $130^{\circ} \mathrm{C}$.

Using Faradays law (eq. 7), the mass loss and depth of corrosion on the metallic surface can be calculated. The mass $m$ of the most promising material Cronix 80 (2.4869) will be reduced after 5000 operating hours at $130^{\circ} \mathrm{C}$ by $213 \mathrm{mg} \mathrm{cm}^{-2}$ and this correlates to an abrasion depth $d$ of nearly $100 \mu \mathrm{m}$ (eq. 8).

$$
\begin{gathered}
\Delta m(i, t)=\frac{j \cdot A \cdot M}{z \cdot F} \int d t_{c o r} \\
V=A \cdot d=\frac{m}{\rho}
\end{gathered}
$$

Table V. Calculated values for $E_{c o r}$ and $j_{c o r}$ at $130^{\circ} \mathrm{C}$ from Figure 9.

\begin{tabular}{cccccc} 
& \multicolumn{2}{c}{$\mathrm{E}_{\mathrm{cor}} / \mathrm{mV}$} & & \multicolumn{2}{c}{$\mathrm{j}_{\mathrm{cor}} / \mu \mathrm{A} \mathrm{cm}^{-2}$} \\
\cline { 2 - 3 } \cline { 5 - 6 } Material & $-0.5-2.0 \mathrm{~V}$ & $0-1.0 \mathrm{~V}$ & & $-0.5-2.0 \mathrm{~V}$ & $0-1.0 \mathrm{~V}$ \\
\hline 1.4301 & 0 & 65 & & 154.44 & 45.59 \\
1.4372 & 0 & 55 & & 192.17 & 48.89 \\
1.4404 & 35 & 60 & & 131.65 & 161.91 \\
1.4571 & 30 & 25 & & 121.04 & 270.88 \\
1.4539 & 13 & 62 & & 57.77 & 39.30 \\
1.4876 & -26 & 6 & & 84.88 & 326.96 \\
2.4819 & 85 & 103 & & 35.37 & 11.79 \\
2.4733 & 80 & 63 & & 171.88 & 92.62 \\
2.4856 & 86 & 75 & & 81.35 & 44.35 \\
2.4869 & -73 & 235 & & 8881.24 & 0.71
\end{tabular}

These values are estimated for conditions at $0.6 \mathrm{~V}$ (cathodic bipolar plate) with following assumptions: anodic current density $j$ is 16.1 $\mu \mathrm{A} \mathrm{cm} \mathrm{cm}^{-2}$, exposed area $A$ of $2.54 \mathrm{~cm}^{2}$, molar mass $M$ of nickel (as reference) is $58.69 \mathrm{~g} \mathrm{~mol}^{-1}$, number of electrons $z$ exchanged in reaction is two, density $\rho$ of Cronix 80 is $8.31 \mathrm{~g} \mathrm{~cm}^{-3}$ and the Faraday constant $F$ of $9.65 \cdot 10^{4}$ As $\mathrm{mol}^{-1}$. This high extent of corrosion would poison the PBI membrane and perforate the bipolar plate. For the anodic bipolar plate that faces $\sim 0 \mathrm{~V}$, it looks less pessimistic. Since $\mathrm{E}_{\text {cor }}$ of $235 \mathrm{mV}$ is positive, the anodic corrosion around $0 \mathrm{~V}$ is inhibited due to cathodic protection.

For comparison, a state of the art graphite composite material with phenolic resin (BBP4 from Eisenhuth), which is proposed for temperatures $<180^{\circ} \mathrm{C}$, was investigated in the same way as the metallic materials. As can be seen in Figure 10, a value of $370 \mathrm{mV}$ for $\mathrm{E}_{\text {cor }}$ concerning both $\mathrm{RT}$ and $130^{\circ} \mathrm{C}$ is relatively high. But on the other side, the anodic corrosion once exceeding $\mathrm{E}_{\mathrm{cor}}$ is rising rapidly. At $\mathrm{RT}$, the current density at $0.6 \mathrm{~V}$ and $0.95 \mathrm{~V}$ is $10.5 \mu \mathrm{A} \mathrm{cm}^{-2}$ and $57.3 \mu \mathrm{A}$ $\mathrm{cm}^{-2}$, compare with $0.4 \mu \mathrm{Acm}^{-2}$ and $2.0 \mu \mathrm{Acm}^{-2}$ for 1.4301 for the same potentials in Figure $8 \mathrm{c}$. At $130^{\circ} \mathrm{C}$, graphite shows tremendous current densities of $57.3 \mu \mathrm{A} \mathrm{cm}^{-2}$ and $201.6 \mu \mathrm{A} \mathrm{cm}^{-2}$ at $0.6 \mathrm{~V}$ and $0.95 \mathrm{~V}$, whereas the most promising material 2.4869 reveals values of only $16.1 \mu \mathrm{A} \mathrm{cm}^{-2}$ and $25.5 \mu \mathrm{A} \mathrm{cm}^{-2}$ at the same polarization. Despite the high corrosion rates, graphitic materials possess two decisive advantages in terms of fuel cell application. Primarily, graphite does not underlie insulating passivation, which results in an increase of the interfacial contact resistance between bipolar plate and gas diffusion layer. And secondly, graphite does not poison the catalyst and the proton conductive membrane since the corrosion products $\mathrm{CO}_{2}$ and $\mathrm{CO}$ are volatile. 


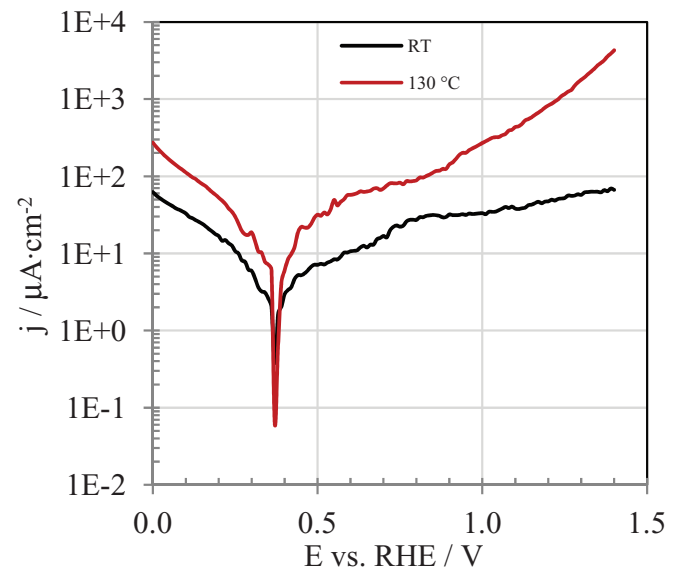

Figure 10. Tafel plots of Graphite composite material measured in $85 \mathrm{wt} \%$ $\mathrm{H}_{3} \mathrm{PO}_{4}$ at $\mathrm{RT}$ and $130^{\circ} \mathrm{C}$ in the potential range $0 \mathrm{~V}-1.4 \mathrm{~V}$.

\section{Conclusions}

In this corrosion study four austenitic stainless steels and six $\mathrm{Ni}$-based alloys were chosen as possible metallic bipolar plates for HT-PEFC application and electrochemically characterized in $85 \mathrm{wt} \%$ $\mathrm{H}_{3} \mathrm{PO}_{4}$ at $\mathrm{RT}$ and $130^{\circ} \mathrm{C}$. The free corrosion potential $\mathrm{E}_{\mathrm{cor}}$, which is an indication for passive layer stability when no external current is applied, was examined as a function of temperature. Cyclic voltammetry and quasi steady-state polarization were performed in order to understand the influence of various elements on passivation and to determine anodic current densities in active and passive potential regions. As conclusion, following core messages can be figured out:

- In the classification of stainless steel, the most common stainless steel 304 (1.4301) with 18\% Cr and 10\% Ni (rest iron) shows surprisingly the best corrosion resistance compared to costly stainless steels with additions of Ti, Mn and Mo. The current density in the region of passivity $(0.2-1.2 \mathrm{~V})$ exhibits the lowest values of $0.4 \mu \mathrm{A} \cdot \mathrm{cm}^{-2}$ at $\mathrm{RT}$ and $37.5 \mu \mathrm{A} \cdot \mathrm{cm}^{-2}$ at $130^{\circ} \mathrm{C}$ at $0.6 \mathrm{~V}$. The corrosion rates at RT are even lower than in the case of all tested Ni-based alloys. Thus, the corrosion resistance is primarily based on an inner $\mathrm{Cr}_{2} \mathrm{O}_{3}$ layer, which is stable in the potential window $0.3-1.2 \mathrm{~V}$ (vs. RHE). The tremendous rise in current at $130^{\circ} \mathrm{C}$ is attributed to a poor stability of the passive layers based on $\mathrm{Fe}$.

- In the category of the Ni-based alloys, material 2.4869 (Cronix 80 ) with $80 \% \mathrm{Cr}$ and $20 \% \mathrm{Ni}$ reveals the lowest corrosion rates in comparison to Ni-based alloys with additions of $\mathrm{Ti}, \mathrm{Cu}, \mathrm{Mo}$ and $\mathrm{Nb}$. The passive current density at $0.6 \mathrm{~V}$ was measured to be $0.9 \mu \mathrm{A} \mathrm{cm}^{-2}$ at RT and $16.1 \mu \mathrm{A} \mathrm{cm}^{-2}$ at $130^{\circ} \mathrm{C}$. Ni passivation takes place at nearly $0 \mathrm{~V}$ at $130^{\circ} \mathrm{C}$, which can be seen by oxidation peaks in voltammograms and by high anodic currents in Tafel plots. The high ratio of nickel release at $0 \mathrm{~V}$ leads in turn to a dominant $\mathrm{Ni}_{3}\left(\mathrm{PO}_{4}\right)_{2}$ film (outer porous layer) in the proceeding passivation. Obviously, the passivation depends strongly on potential and therefore, this severe impact should be considered in terms of operating conditions of the fuel cell.

- An increasing amount of Mo in alloys shows a shift of $E_{\text {cor }}$ to more positive values at $130^{\circ} \mathrm{C}$. But, passive layers containing Mo are not stable under anodic polarization. Material 2.4819 with $16 \%$ Mo shows a current rise in Tafel plots beyond $0.3 \mathrm{~V}$ at $130^{\circ} \mathrm{C}$.

- A positive effect of small amounts of Ti on corrosion (316 Ti and Nicrofer $3220 \mathrm{H}$ ) can be seen only for $\mathrm{E}_{\text {cor }}$ at RT. At $130^{\circ} \mathrm{C}$, the passivation based on Ti support is not stable anymore. By means of steady-state polarization, Ti dissolution can be observed at a potential of $0.10-0.15 \mathrm{~V}$.
- Further, a slight reduction of passive current density has been achieved through addition of $\mathrm{W}$ in material 2.4733 (Heynes 230 alloy). A beneficial effect of $\mathrm{Nb}$ in material 2.4856 (alloy 625 ) could not be observed.

The required corrosion current densities lower than $1 \mu \mathrm{A} \mathrm{cm}^{-2}$ for anodic and cathodic conditions ${ }^{4}$ could not be achieved. Based on the results from this study, it is not feasible to employ bare commercially available stainless steels or Ni-based alloys as metallic bipolar plates for HT-PEFC application. On the one hand, the typical operating temperature of a HT-PEFC lies within a range of $160-180^{\circ} \mathrm{C}$ and this would imply even higher corrosion rates than obtained in this work at $130^{\circ} \mathrm{C}$. And on the other hand, it should be also taken into account that in a fuel cell there is distinctly less phosphoric acid in contact with the bipolar plate $\left(\sim 1 \mathrm{mg} \mathrm{cm}^{-2}\right)$. Consequently, corrosion is going to be reduced or even inhibited due to a saturation of the present wetted acid film. Further it has to be considered that the enhanced concentration of metal cations will increase the $\mathrm{pH}$ in the thin acid film and thus change the stability of passivation. Both effects are important parts of ongoing research activities. To overcome corrosion and the rise of the contact resistance but to keep the benefits of metals, one possibility could be applying conductive and inert coatings. Studies on various promising ceramic and graphitic coatings are currently in progress. Additionally, the increase of the interfacial contact resistance, which results from passivation of metallic materials, is also going to be considered.

\section{Acknowledgments}

We thank the companies Gräbener Maschinentechnik GmbH \& Co. KG, Wickeder Westfalenstahl GmbH and Zapp Materials Engineering $\mathrm{GmbH}$ for providing the analyzed metallic materials. This work was executed as a part of the project RoBiPo supported by BMWi, the German Ministry for Economy and Technology (project number 03ET2030F).

\section{References}

1. L. G. Christner, H. P. Dhar, M. Farooque, and A. K. Kush, Corrosion, 43, 571 (1987) 2. A. J. Appleby, Corrosion, 43, 398 (1987).

3. C. Hartnig and T. J. Schmidt, Electrochim. Acta, 56, 4237 (2011).

4. R. A. Antunes, M. C. L. Oliveira, G. Ett, and V. Ett, International Journal of Hydrogen Energy, 35, 3632 (2010).

5. D. Papageorgopoulos, in 2012 Annual Merit Review and Peer Evaluation Meeting, U. S. D. o. Energy Editor (2012).

6. H. Tsuchiya and O. Kobayashi, International Journal of Hydrogen Energy, 29, 985 (2004).

7. G. Kreysa and M. Schütze, Corrosion Handbook, Wiley-VCH, Weinheim, DECHEMA (2004).

8. R. J. Fabian and J. A. Vaccari, Materials Engineering, 73, 36 (1971).

9. P. R. Kosting and C. Heins, Industrial and Engineering Chemistry, 23, 140 (1931).

10. C. Escriva-Cerdan, E. Blasco-Tamarit, D. M. Garcia-Garcia, J. Garcia-Anton, R. Akid, and J. Walton, Electrochim. Acta, 111, 552 (2013).

11. C. Escriva-Cerdan, E. Blasco-Tamarit, D. M. Garcia-Garcia, J. Garcia-Anton, and A. Guenbour, Corrosion Sci., 56, 114 (2012).

12. P. Kritzer, N. Boukis, and E. Dinjus, Materials and Corrosion-Werkstoffe Und Korrosion, 49, 831 (1998).

13. P. Kritzer, N. Boukis, and E. Dinjus, Corrosion Science Section, 56, 1093 (2000).

14. S. Elhajjaji, L. Aries, J. P. Audouard, and F. Dabosi, Corrosion Sci., 37, 927 (1995).

15. H. A. El Dahan, Journal of Materials Science, 34, 859 (1999).

16. C. R. Clayton and Y. C. Lu, Journal of the Electrochemical Society, 133, 2465 (1986).

17. C. R. Clayton and Y. C. Lu, Corrosion Sci., 29, 881 (1989).

18. A. Guenbour, J. Faucheu, and A. Benbachir, Corrosion, 44, 214 (1988).

19. A. Guenbour, M. Essahli, A. Benbachir, L. Aries, and R. Boulif, Acta Chimica Slovenica, 50, 287 (2003).

20. A. C. Lloyd, J. J. Noel, S. McIntyre, and D. W. Shoesmith, Electrochim. Acta, 49 3015 (2004).

21. J. Andre, L. Antoni, and J. P. Petit, International Journal of Hydrogen Energy, 35, 3684 (2010)

22. J. Richards and K. Schmidt, Review - Metallic Bipolar Plates and their Usage in Energy Conversion Systems, p. 30 Frauenhofer Institute for Chemical Technology, Wolfsburg.

23. H. Tawfik, Y. Hung, and D. Mahajan, J. Power Sources, 163, 755 (2007).

24. H. Wang and J. A. Turner, Fuel Cells, 10, 510 (2010),

25. H. L. Wang and J. A. Turner, J. Power Sources, 180, 803 (2008). 
26. M. Kouril, E. Christensen, S. Eriksen, and B. Gillesberg, Materials and Corrosion-Werkstoffe Und Korrosion, 63, 310 (2012).

27. A. V. Nikiforov, I. M. Petrushina, E. Christensen, A. L. Tomas-Garcia, and N. J. Bjerrum, International Journal of Hydrogen Energy, 36, 111 (2011).

28. A. Robin and J. L. Rosa, International Journal of Refractory Metals \& Hard Materials, 18, 13 (2000).

29. R. C. Bhardwaj, M. A. Enayetullah, and J. O. Bockris, Journal of the Electrochemical Society, 137, 2070 (1990).

30. F. Gan and D. T. Chin, Journal of Applied Electrochemistry, 23, 452 (1993).
31. K. E. Gubbins and R. D. Walker, Journal of the Electrochemical Society, 112, 469 (1965).

32. M. Finsgar, Corrosion Sci., 68, 51 (2013).

33. A. Pardo, M. C. Merino, A. E. Coy, F. Viejo, R. Arrabal, and E. Matykina, Corrosion Sci., 50, 1796 (2008).

34. A. Pardo, M. C. Merino, A. E. Coy, F. Viejo, R. Arrabal, and E. Matykina, Corrosion Sci., 50, $780(2008)$

35. A. Mitsuhashi, K. Asami, A. Kawashima, and K. Hashimoto, Corrosion Sci., 27, 957 (1987). 